\title{
EXPLORING FACTORS TO BUILD RAPPORT BETWEEN INTERVIEWER AND RESPONDENT: INSIGHTS FROM THE NATIONAL RESEARCH ON DOMESTIC VIOLENCE AGAINST WOMEN IN TURKEY ${ }^{1}$
}

\author{
Melike SARAÇ \\ Ahmet Sinan TÜRKYILMAZ ${ }^{3}$
}

\begin{abstract}
Examining interviewing process in terms of interviewers and respondents are crucial due to their major roles on survey estimates, cooperation and non-response. The rapport between interviewers and respondents plays a critical role on disclosure of answers and response quality. Therefore, there is a need to unveil factors behind rapport from interviewers' and respondents' perspectives. We aim to explore factors to build rapport and investigate variation among subgroups whose interviews conducted with high rapport. This study utilizes the National Research on Domestic Violence against Women in Turkey (2014) data and Field Staff data to achieve objectives. Our findings suggest that timing and frequency of visits, interviewer characteristics and similarity, and dynamic interview factors are essential when building rapport. The study also points out that there are statistically significant variations among women by socio-demographic and socio-economic characteristics as well as sensitive variables such as exposure to violence and controlling behaviors by husbands.
\end{abstract}

Keywords: Respondent, Interviewer, Rapport, Violence, Exploratory Factor Analysis, Turkey

${ }^{1}$ This article is based on a part of the PhD thesis entitled "The Contribution of Interview Rapport on Data Quality from NonSampling Error Perspective: Evidence from 2013 Turkey Demographic and Health Survey and 2014 Research on Domestic Violence against Women in Turkey" preparing by Melike Saraç, at Hacettepe University, Institute of Population Studies, Department of Social Research Methodology, Ankara, Turkey.

${ }^{2}$ Arş. Gör. Hacettepe Üniversitesi Nüfus Etütleri Enstitüsü, Sosyal Araştırma Yöntemleri Anabilim Dalı

${ }^{3}$ Prof. Dr. Hacettepe Üniversitesi Nüfus Etütleri Enstitüsü, Sosyal Araştırma Yöntemleri Anabilim Dalı

SAD / JSR

Cilt / Volume 23 Sayı / Number 2 


\section{GÖRÜSMECİ VE CEVAPLAYICI ARASINDAKİ UYUMU OLUSTTURAN FAKTÖRLER: TÜRKIYYE'DE KADINA YÖNELIKK AİLE İÇİ ŞIDDET ARAŞTIRMASINA DAYALI BULGULAR}

\section{ÖZ}

Görüşme sürecini görüşmeciler ve cevaplayıcılar açısından incelemek, görüşmeciler ve cevaplayıcıların araştırma tahminleri, iletişim ve cevapsızlık gibi konulara olan etkileri nedeniyle oldukça gereklidir. Görüşmeci ve cevaplayıcı arasındaki uyum, cevapların beyan edilmesi ve kalitesinde önemli rol oynamaktadır. $\mathrm{Bu}$ nedenle, görüşmeciler ile cevaplayıcılar arasındaki uyumu oluşturan faktörleri görüşmeciler ve cevaplayıcılar açısından ortaya çıkarmaya ihtiyaç duyulmaktadır. Bu çalışmanın amaçları, görüşmeciler ile cevaplayıcılar arasındaki uyumu oluşturan faktörleri keşfetmek ve görüşmeleri yüksek uyum ile gerçekleşmiş cevaplayıcılar arasındaki farklılıkları göstermektir. Çalışmada, 2014 yılında gerçekleşen Türkiye'de Kadına Yönelik Aile İçi Şiddet Araştırması ve bu araştırmanın Saha Personeli verileri kullanılmaktadır. Bulgular, ziyaretlerin zamanlaması ve sıklığı, görüşmeci özellikleri ve benzerlik ile dinamik görüşme faktörlerinin uyumu oluşmasında önemli kavramlar olduğunu ortaya koymaktadır. Ayrıca sonuçlar, görüşmeleri yüksek uyum ile tamamlanmış kadın grupları arasında sosyo-demografik ve sosyo-ekonomik özellikler ile şiddete maruz kalma ve eş tarafından uygulanan kontrol edici davranışlar gibi hassas değişkenlere göre belirgin farkl1lıklar olduğunu göstermektedir.

Anahtar kelimeler: Cevaplayıc1, Görüşmeci, Uyum, Şiddet, Keşfedici Faktör Analizi, Türkiye 


\section{INTRODUCTION}

There is a growing demand for high quality survey estimates to understand social phenomena in a society and mechanisms behind these. Sample surveys, which provide detailed data on a large range of matters, provide useful information through a representative sample. In addition to considerable methodological studies which focus on data quality (Channon, Padmadas and McDonald, 2011; Corsi, Perkins and Subramanian, 2017), it is known that interviewer and respondent play considerable role at the data collection stage in interviewer-administrated social surveys. These main actors of interviewing can produce measurement and non-response errors that could be originated from lack of accuracy or completeness of responses. In survey methodology field, there are numerous studies that deal with interviewer and respondent as well as the impact of their characteristics on survey cooperation, response behavior, measurement and quality (Berk and Bernstein, 1988; Campanelli, Sturgis and Purdon, 1997; Davis, Couper, Janz, Caldwell and Resnicow, 2009; Durrant, Groves, Staetsky and Steele, 2010; Flores-Macias and Lawson, 2008; Hox et al., 2002; Olson and Peytchev, 2007; Pickery, Loosveldt and Carton, 2001).

Importantly, the interaction between interviewer and respondent might have a considerable impact on getting accurate and complete answers, yet little is known about determinants and level of rapport between interviewer and respondent. There are only a few qualitative studies to understand interviewing process from the cognitive perspective (Belli, Lepkowski and Kabeto, 2001; Foucault Welles, 2010; Van der Zouwen, Dijkstra and Smit, 2004). There is a lack of quantitative studies which identify the rapport between interviewer and respondent and investigate its influence on survey outcomes. The gap in the literature might be associated with the uncertainty of the rapport meaning. Indeed, impalpable meaning of the rapport and difficulty to describe it had been mentioned in related studies (Garbarski, Schaeffer and Dykema, 2016; Goudy and Potter, 1975; Schober, 2016). The authors discussed the rapport in conjunction with the certain 
concepts such as social distance, comfort, willingness, motivation, demographic similarity, interviewing technique, and social desirability bias (Dijkstra, 1987; Garbarski et al., 2016; Sheatsley, 1951).

Cooperation with the sample unit, developing rapport during the interview and keeping motivation of respondent on a high level are noteworthy issues when assessing interviewer individuality, survey standardization and high quality responses. Olson and Bilgen (2011) identified the rapport as a positive friendly environment and suggested that building rapport may lead to better data quality. Similarly, Belli et al. (2001) argued that conversational rapport may have an impact on response accuracy through increased motivation of respondents to cooperate with the survey request. Green and Krosnick (2001) also stated that rapport might help to trigger respondents to work hard and thus, provides high quality data in face to face surveys. In line with these statements, Dijkstra (1987) and Sun (2014) pointed out that building strong rapport may help to produce reliable and valid reports especially for sensitive questions although a few studies have found the contrary findings (Weiss, 1968). On the other hand, there are also a few studies which indicate no relationship between rapport and validity of responses (Belli et al., 2001; Goudy and Potter, 1975).

Given this background and Lavin and Maynard (2001) suggested, it is obvious that rapport is still need to be well-defined considering both respondent and interviewer characteristics. Furthermore, investigating variation among women who achieve high rapport is remarkable effort considering the growing emphasis on gaining cooperation, maintaining motivation and getting high quality data. Therefore, exploration and understanding of rapport concept and examining high rapport variation across groups still require further studies. Accordingly, the current quantitative study has two main research questions: (1) what are the concepts to build rapport between interviewer and respondent? (2) which subgroups of women differ from each other in terms of establishing high rapport? 
To the best of authors' knowledge, this is the first methodological paper in Turkey that identifies rapport between interviewer and respondent and reveals significant variation among women groups whose interviews conducted with high rapport, in particular by sensitive information provided by the Research on Domestic Violence against Women in Turkey (VAW study). In view of the recent emphasis on the association between sensitivity and rapport in surveys, an effort on exploring components to build rapport for a sensitive survey conducted in Turkey seem to be valuable. Furthermore, the findings of the study are expected to provide a new insight to clarify interaction between interviewing actors, considering interviewer and respondent characteristics as well as interview related factors.

This paper is divided into five main sections. The first section presents the need and motivation of the study in light of current literature and study objectives. The second section reviews literature on interviewer and respondent as well as interaction established by them. The third section introduces data sources, provides constructed variables and statistical techniques to achieve study objectives. The fourth section explores the rapport between interviewer and respondent through selected variables and focuses on significant variation among women by various characteristics. The fifth section discusses study findings together with current literature and future studies.

\section{LITERATURE AND THEORETICAL FRAMEWORK}

\subsection{Literature}

Interviewer impact on survey cooperation and response quality have been examined and assessed in recent studies (Durrant et al., 2010; Oyinlade and Losen, 2014; Vercruyssen, Wuyts and Lossveldt, 2017). Age, gender, education, experience and interviewer expectations are most studied interviewer characteristics when investigating interviewer impact on survey participation (Amos, 2018; Hansen, 2006; Hox, De Leeuw and Kreft, 1991; Lipps and Lutz, 2010; Pickery et al., 2001; Singer, Frankel and Glassman, 1983). On the 
other hand, as Durrant et al. (2010) suggested, there are limited surveys that collect detailed information on interviewers and the limitation leads to lack of studies that investigate interviewer variance.

Rapport does not exactly mean interaction and it is hard to explain concept because of its impalpable meaning and using in different ways. Although rapport was handled in studies, there are no unique features and aspects to build and maintain rapport (Garbarski et al., 2016). Unobservable nature of interaction, feeling of connection, mutual comfort, feeling comfortable, respondent cooperation, coordination, interview difficulty, sense of connection, ease of conversational connection and interest, harmonious and friendly relationship, social distance are among the measures of rapport in the literature (Capella, 1990; Davis et al., 2009; Foucault Welles, 2010; Garbarski et al., 2016; Goudy and Potter, 1975; Weiss, 1968). Overall, meaning of rapport is inconclusive and as stated by Bell, Fahmy and Gordon (2016) rapport meaning may vary from over-friendliness to professional neutrality. Moreover, Sun (2014) and TickleDegnen and Rosenthal (1990) addressed that rapport is a dynamic and interactive phenomenon which emerge from each individual during the interview.

Physical features such as eye contact and frequency of smiles and nods are suggested to describe rapport (Gubrium, Holstein, Marvasti and McKinney, 2012). Additionally, interviewers' and respondents' assessments on degree of rapport and comfortable feeling were taken to measure rapport (Goudy and Potter, 1975; Weiss, 1968). Interviewers' non-verbal behaviors, smiling, nodding and direct gazes, were examined and interviewer smiling and nodding were found to be significant when developing rapport (Foucault Welles, 2010). Moreover, Goudy and Potter (1975) put forward that there may be no linkage between interviewer performance and rapport. Interviewing technique was mentioned as another factor to establish rapport due to the fact that standardized interviewing may restrain degree of rapport (Fowler $\mathrm{Jr}$ and Mangione, 1990; Sheatsley, 1951). 
Interviewer-respondent similarity is argued under the examination of nonresponse and response accuracy.

In the recent studies, impact of socio-demographic (mis)match between interview actors was handled on item level non-response in face to face interviews (Durrant and D'Arrigo, 2014; Durrant et al., 2010; Vercruyssen et al., 2017). On the other hand, stating affirmative responses to attitude questions was argued under the impact of gender and age dissimilarity between interviewer and respondent (Oyinlade and Losen, 2014). In the earlier studies, interviewer-respondent similarity in terms of demographics such as age, education, socio-economic status and attitudes was discussed within the context of rapport and response accuracy (Sheatsley, 1951; Weiss, 1968). For instance, matching of ethnicity was found as an influential factor on why less conservative answers were given to race questions (Williams Jr, 1968).

Not only identifying factors to build rapport, at the same time ways to determine rapport level is important in order to evaluate degree of rapport. Tickle-Degnen and Rosenthal (1990) described high level of rapport along with high level of mutual attentiveness and positivity. In a study conducted by Weiss (1968), degree of rapport was classified as confiding, frank, equivocal, guarded and hostile based on interviewers' assessments at the end of the interview. Foucault, Aguilar, Miller and Cassel (2013) used an interview situation scale that includes relaxed, cooperative, and unfriendly measures to determine degree of rapport. Johnson, Fendrich, Shaligram, Garcy and Gillespie (2000) created social distance index which refers to points between 0 and 4 when determining low and high rapport. Dijkstra (1987) and Williams Jr (1968) argued curvilinear structure of rapport level when explaining association between rapport level and response validity. In other words, optimal rapport level is found to be efficient rather than extreme values of rapport.

The discussions towards rapport remind sensitivity and social desirability in survey methodology literature. Gubrium et al. (2012) stated that rapport may be defined as level of feeling embarrassment as response to sensitive questions. Biemer and Lyberg (2003) also emphasized the huge impact of rapport on survey 
interests that are prone to social desirability bias. In line with these studies, Schober (2016) suggested that the rapport building behaviors might be detected in response validity especially for sensitive questions on embarrassing and illegal behaviors. Van der Zouwen et al. (2004) argued that less socially desirable answers to sensitive questions were provided by respondents when the rapport is built during interview. Similarly, Dijkstra (1987) has also found that respondents provide more sensitive information in personal interviews with the help of supporting behaviors of interviewers. In face to face experimental study the extensive study, positive impact of rapport was detected on disclosure of sensitive questions (Sun, 2014). Furthermore, respondents' tendency to be influenced from socio-demographic characteristics of interviewers was examined through the comparison between answers to sensitive questions and factual questions (Davis et al., 2009; Schnell and Kreuter, 2005). In contrast to positive impact of rapport on disclosure of sensitive questions, too high rapport may result in lower validity due to response bias (Mensch and Kandel, 1988). Similarly, Weiss (1968) put forward that better rapport result in large proportion of biased answers due to the fact that respondents have a tendency to give more socially desirable answers.

Apart from main actors of interviewing and their interaction, impact of interview related factors such as presence of third person, namely translator, mode of data collection, field stage and timing of interview were investigated within the context of developing quality of data as well as rapport between interviewer and respondent (Johnson, Grant, Khan, Moore and Armstrong, 2009; Sun, 2014).

In light of the findings of the previous studies, it could be concluded that there is an inconclusive literature on meaning and level of rapport as well as its impact on responses. This is probably originated from varying aspects of rapport and different methodologies adopted in the studies. 


\subsection{Theoretical Framework}

Liking theory and the concept of social distance could be associated with the study that examines the matching characteristics between interviewer and respondent when building rapport. Liking theory asserts that respondents would like to interact with the interviewers who share similar experiences and have similar characteristics. In other words, according to liking theory, social interaction between individuals is shaped by whether they like each other or not. This similarity leads to more willingness to establish harmonious relationships (Groves, Cialdini and Couper, 1992). Furthermore, similarity on attitudes, religiousness and background between individuals are the essential factors to enhance liking (Byrne, 1971; Stotland and Patchen, 1961; Drachman, de Carufel, and Insko, 1978), and it can be practiced in survey settings to build rapport between interviewers and respondents. In light of this theory, we expect an impact of the existing similarities between interviewers' and respondents' socio-demographic characteristics when establishing relationship during the interview. In other words, rapport between interviewers and respondents might be affected from whether they have shared similar socio-demographic characteristics or not.

Concept of social distance also refers to similarities between individuals in terms of social class and ethnicity as well as age and gender (Katz, 1942; Lipman-Blumen, 1976; Weeks and Moore, 1981). Hodgetts and Stolte (2014) described the social distance as experiencing a sense of (un)familiarity between individuals in terms of having different social, ethnic, religious or occupational groups. Furthermore, race and social class differences between people are used jointly to describe social distance (Williams, 1964). Based on this concept, interviewers and respondents might be in different ages or social classes, and they may have different educational levels. Considering the liking theory and social distance concept, the impact of dis(similarity) could be remarkable influence to build rapport between those actors. 


\section{METHODOLOGY}

\subsection{Data Sources}

The main data source of this study comes from Research on Domestic Violence against Women in Turkey which was conducted in 2014. In Turkey, the nationally representative household survey was carried out by the Hacettepe University Institute of Population Studies in collaboration with Turkish Republic Ministry of Family and Social Policies the General Directorate on the Status of Women. The survey aims to collect nationally representative data on women's background characteristics, prevalence and consequences of violence against women, and coping strategies for violence against women by conducting face to face interviews.

The main survey theme, domestic violence, is such a sensitive issue that many ethical rules such as safe name use "Turkey Women and Family Survey", interviewing one woman per household, signing an informed consent form by interviewer to indicate respondent approval and conducting the interview in a private setting were taken into account in line with the Ethical and Safety Guidelines (WHO Department of Gender and Women's Health, 2001). Firstly, an adult member aged 15 and older in households was interviewed by using household questionnaire. Once the household interview was completed, a woman who is between 15 and 59 was selected randomly among all eligible women in that household using Kish table. Most of the questions in the household and woman questionnaires were prepared on the basis of "Multicountry study on Women's Health and Domestic Violence against Women" which was carried out by World Health Organization. Out of 11,247 households with completed interviews, 7,462 women were interviewed in the survey (GDSW and HUIPS, 2015).

Women data set provides not only information on background characteristics and violence exposure of women but at the same time interview related variables, opinions and feelings of interviewer. The study mainly use interview related variables, opinions and feelings of interviewer and certain respondent 
characteristics at the rapport index construction. Still, the study requires additional data source that provides information on interviewer characteristics for multidimensional examination of rapport. To compensate this need, field staff data set was constructed and utilized to reach study objectives. Field staff data set provides information about socio-demographic characteristics of 104 fieldworkers, which were obtained through recruitment forms to work. In order to conduct analyses, women and field staff data sets were merged identifying interviewer identification number as a key variable. Hence, analyses were conducted by using the merged data set.

\subsection{Variables}

In the process of rapport index construction, which is the first stage of the analyses, variables which describe interview environment and field staff were used. Furthermore, basic characteristics of respondents were used to measure variables that denote similarity between interviewer and respondent. Interviewer related variables include interviewer characteristics, opinions and feelings, performance indicators, and similarity with the respondent. The variables which refer to similarity were only constructed based on `age' (up to 5 years), 'educational level', and 'region' differences due to the limited information.Regional matching was also considered with place of birth of interviewers and respondents' place of residence up to 12 years due to the data availability. Considering performance indicators, 'cooperation rate' denotes the proportion of completed women interviews over all women interviews per interviewer. 'Mean duration' denotes mean length of interview per interviewer and calculated with the information of interview's start and end times. The cut-off values were specified based on mean values. Interview related variables comprise timing of visits, field and visits, length of interviews and other interview related variables. 'Field stage' was constructed based on first month of the fieldwork (April) and later (May, June, July). 'Language matching' refers to similarity between interview language and respondent's mother tongue. 
In the first stage of the study, most of the variables were selected based on the previous literature on establishing rapport and survey quality assessments. Furthermore, fieldwork experiences were considered when selecting variables regarding interviewer performance, field and visits. All variables in the process of rapport index construction are presented in Table 1.

Table 1. Variables used in the principal component analysis

\begin{tabular}{|c|c|c|c|}
\hline \multicolumn{2}{|l|}{ Interviewer related variables } & \multicolumn{2}{|c|}{ Interview related variables } \\
\hline Interviewer characteristics & Similarity & Timing of visits & Other variables \\
\hline Experience* & Age & Start hour & Translator use* \\
\hline No & Not matched & 9-11 AM or 6-10 PM & Used \\
\hline Yes & Matched & 11-12 AM or 1-6 PM & Not used \\
\hline Enrolled student & Educational level & Interview day* & Language matching \\
\hline No & Not matched & Weekday & Not matched \\
\hline Yes & Matched & Weekend & Matched \\
\hline Background & Region* & Timing & $\begin{array}{l}\text { Presence of mother-in-law } \\
\text { in household* }\end{array}$ \\
\hline Natural sciences & Not matched & Morning or evening & No \\
\hline Social/educational sciences & Matched & Afternoon & Yes \\
\hline Opinions and feelings & $\begin{array}{l}\text { Performance } \\
\text { indicators }\end{array}$ & Field and visits & Length of interviews \\
\hline Reliability of answers & Cooperation rate* & Field stage & $\begin{array}{l}\text { Interview length } \\
\text { Less than } 21 \text { or more than } 89\end{array}$ \\
\hline Poor or medium & More than 1.15 & Beginning & minutes \\
\hline Good or very good & Less than 1.16 & Middle or end & Between 20 and 89 minutes \\
\hline Feelings after the interview & Mean duration & Number of visits & Break duration* \\
\hline Bad or worse & minutes & 1 or 2 & More than 10 minutes \\
\hline $\begin{array}{l}\text { Good, better, same or no } \\
\text { difference }\end{array}$ & $\begin{array}{l}34.6 \text { minutes or } \\
\text { higher }\end{array}$ & 3 and more & None or less than 10 minutes \\
\hline
\end{tabular}

In the second stage of the study, variation among women groups who have high level of rapport were investigated based on demographic/basic characteristics, socio-economic characteristics, violence related variables, attitudes and other variables. Certain variables were converted to index type variables through the principal component analysis and then those were classified into sub-categories. All variables for the second stage analyses are presented in Table 2. 
Table 2. Variables used in the Complex Samples Generalized Linear Model (CSGLM)

\begin{tabular}{|c|c|c|c|c|}
\hline Demographic/basic & Socio-economic & Violence related & Attitudes & Other variables* \\
\hline Region & Educational level & $\begin{array}{l}\text { Emotional } \\
\text { violence }^{\mathrm{a}}\end{array}$ & $\begin{array}{l}\text { Opinions towards } \\
\text { gender roles } \\
\text { Justifications }\end{array}$ & $\begin{array}{l}\text { Presence of mother- } \\
\text { in-law }\end{array}$ \\
\hline Type of residence & Working status & Sexual violence ${ }^{b}$ & $\begin{array}{l}\text { towards violence } \mathrm{f}^{\mathrm{f}} \\
\text { Refusals to have }\end{array}$ & Translator use \\
\hline Age & Wealth index & $\begin{array}{l}\text { Physical violence } \\
\text { Severity of }\end{array}$ & $\operatorname{sex}^{\mathrm{g}}$ & Interview day \\
\hline Mother tongue & $\begin{array}{l}\text { Income status } \\
\text { Spending }\end{array}$ & $\begin{array}{l}\text { violence } \\
\text { Controlling }\end{array}$ & & Break duration \\
\hline $\begin{array}{l}\text { Marital status } \\
\text { Living children } \\
\text { Use of contraception }\end{array}$ & earnings & $\begin{array}{l}\text { behaviors }^{\mathrm{d}} \\
\text { Suicidal thoughts } \\
\text { Physical injuries }\end{array}$ & & $\begin{array}{l}\text { Regional similarity } \\
\text { Cooperation rate }\end{array}$ \\
\hline $\begin{array}{l}\text { Children under } 5 \\
\text { General health }\end{array}$ & & $\begin{array}{l}\text { Violence and } \\
\text { health }\end{array}$ & & \\
\hline
\end{tabular}

*refers to variables that were excluded from final model of the principal component analysis that's why those were used in pairwise comparison.

The categories of the variables will be presented with the study findings.

${ }^{\text {a}}$ Emotional violence is measured in the VAW study with exposure to four different acts of violence (i) insulting/cursing, (ii) humiliating/belittling, (iii) intimidating (iv) threatening to hurt the woman or someone she loves.

${ }^{b}$ Sexual violence is measured in the VAW study with exposure to three different acts of violence (i) forced sexual intercourse (ii) having sexual intercourse when she did not want to because she was afraid (iii) being forced to do something sexual that she found degrading or humiliating.

${ }^{\mathrm{c}}$ Physical violence is measured in the VAW study with the acts of violence (i) slapped her or threw something at her (ii) pushed or shoved her (iii) hit her with his punch (iv) kicked, dragged her or beat her up (v) choked or burned her (vi) threatened to use or actually used a gun, knife or other weapons against her.

${ }^{\mathrm{d} C o n t r o l l i n g}$ behaviors was constructed based on the women's statements on her relationship with her husband/partner:'trying to keep woman from seeing her friends', 'trying to restrict/prevent contact with her family of birth and close relatives', 'insisting on knowing where women she is at all times', 'ignoring her and showing lack of interest in her', 'getting angry if she speak with another man', 'being suspicious that she is unfaithful', 'expecting her to ask his permission to go to a health institution in case of her health problems', 'interfering with the clothes she wears and wanting her to dress as he wants', 'interfering with the clothes she wears and wanting her to dress as he wants', 'interfering with her use of social network sites such as Facebook or Twitter'.

'Opinions towards gender roles includes the items 'not arguing with the husband and keeping silent if woman disagrees with him', 'spending her own money according to her own will', 'doing housework like cooking, dishwashing, laundry and ironing by men', 'necessary to beating children to discipline them', 'responsibility of attitudes and behaviors of a woman by men'.

${ }^{\mathrm{f}}$ Justifications towards violence refer to approval of beating the wife by husband. It involves the items ' $n e$ glecing the housework', 'objecting to her husband', 'refusing to have sexual intercourse with husband', 'asking husband whether he has other relationships', 'suspecting of man that she is unfaihful', 'finding out that she has been unfaithful'.

${ }^{\text {g}}$ Refusal to have sex refers to refusing sex with her husband and was generated based on the items 'not to want', 'his drinking', 'having health problems', 'mistreating her'.

$\mathrm{SAD} / \mathrm{JSR}$

Cilt / Volume 23 Say1 / Number 2 


\subsection{Statistical Methods}

\subsubsection{Exploratory Factor Analysis}

Exploratory factor analysis method is a widely used statistical technique in many disciplines to develop standard measures for unobservable concepts such as satisfaction, social status and social and physical activity (Fernandez-Ballesteros, Zamarron and Ruiz, 2001; Wang, Tolson, Chiang and Huang, 2010). As Fabrigar and Wegener (2011) stated, exploratory factor analysis is used with the aim of reaching an integrated form of a set of measured covariates based on the correlations among those. This multivariate method provides to understand relation structure of data (Hair, Black, Babin, Anderson and Tatham, 1998).

In accordance with the study objectives, principal component analysis was adopted for the first stage of the study. A rapport index was constructed through a set of variables to measure rapport between interviewer and respondent. The emerged factors to explore rapport were evaluated based on the Eigen values and factor loadings. To reach the study objectives, variables which have relatively low factor loadings and covariates that reveal unexpected contribution to build rapport were excluded from the analysis to improve the model fitting. The principal component analysis was conducted using SPSS 23, which is licensed statistical analysis software package for social survey data.

Final results of the exploratory analyses indicate three different factors that contribute to rapport between interviewer and respondent. Explained variances of these factors have almost equal weights, ranging from approximately 10 percent to 12 percent, that's why each of those were named according to common features of variables. The total factor value was calculated with the combination of the factor values.

Once the exploration phase of the study was completed, rapport levels were determined by aggregating factor values into subgroups. The values within the third quartile of rapport index was recoded into 'high' category whilst remaining were recoded into 'low/middle' category. The main reason behind this aggregation is to evaluate degree of rapport without any bias.

SAD / JSR

Cilt / Volume 23 Sayı / Number 2 


\subsubsection{Descriptive Analyses and Pairwise Comparisons}

In the descriptive analysis phase, percentage distribution of women whose interviews completed with high and low/middle rapport and total number of women were presented by women characteristics. In the pairwise comparisons, a binary variable that denotes whether an interview was completed with high rapport was defined. The study variable for the pairwise comparisons as the following:

$$
y= \begin{cases}0, & \text { low or middle rapport } \\ 1, & \text { high rapport }\end{cases}
$$

Afterwards, the proportions of women who have high rapport levels were compared to each other in order to reveal variation among women groups. The null hypothesis was constructed that there is no difference among subgroups in terms of developing high rapport during the interviews. It was required to consider design variables such as stratum and cluster information because of the complex sample design of the VAW study. Therefore, analyses for the pairwise comparisons were conducted using SPSS Complex Samples General Linear Model (CSGLM) procedure. Findings of the models were evaluated considering 5\% and $1 \%$ significance levels.

The $\mathrm{p}$-value for the two-sided test is given based on the

$$
P(|T|)>\left|t\left(\hat{B}_{i}\right)\right|, \quad\left|t\left(\hat{B}_{i}\right)\right|=\frac{\hat{B}_{i}}{S E\left(\hat{B}_{i}\right)}
$$

where $T$ is a random variable from the $t$ distribution and $H_{0_{i}}: \hat{B}_{i}=0$.

The women who aged between 15 and 59 consist of unit of analysis for both stage. Rapport index construction was conducted for 6,967 women due to missing information on interviewer identification number and certain selected variables to build rapport. On the other hand, pairwise comparisons were 
conducted over 2,323 women because of the high rapport restriction. Number of women for the rapport index construction and pairwise comparisons is presented in Figure 1.

Figure 1. Number of women based on study variable

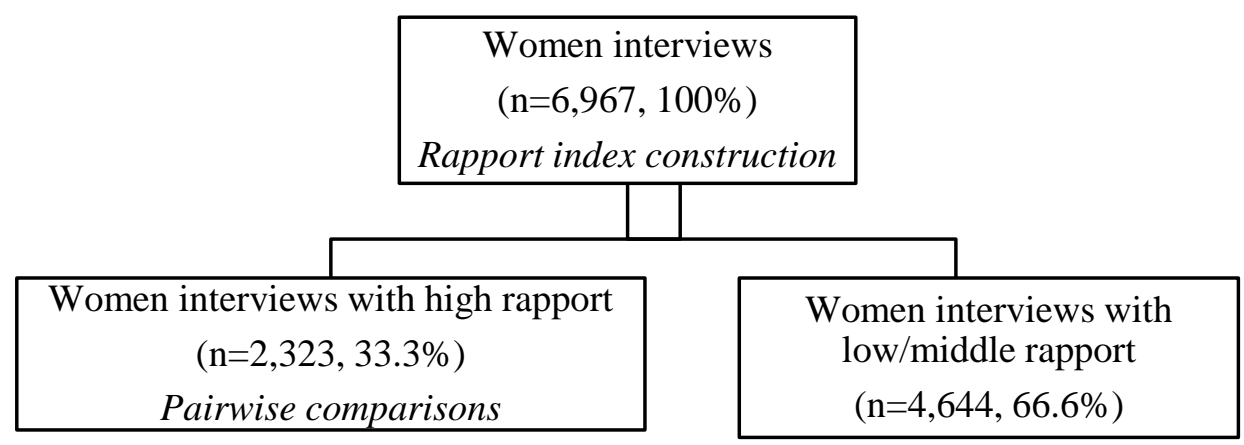

\section{RESULTS}

\subsection{Rapport Index}

Final results of the principal component analyses provide information about factorability of given variables to explore rapport between interviewer and respondent $(\mathrm{KMO}$ coefficient=0.5). Eigen values of the factors are found greater than 1 , referring to positive contribution to build rapport. Results of exploratory analysis also show that total explained variance by three factors was estimated as 33 percent.

Considering the factor loadings of variables, first factor could be associated with the start hour, timing, and number of visits. For the second factor, enrolled student, background, field stage, similarity on age and educational level result in high factor loadings. Lastly, reliability of answers, mean duration, interview length, and language matching and feelings after the interview could be associated with third factor. In other words, first factor refers to fix factors and was labelled as "timing and frequency of visits", second factor refers to characteristics of interviewer and respondent and was labelled as "interviewer characteristics and similarity", and last factor refers to flow factors of interview and was labelled as “dynamic interview factors".

$\mathrm{SAD} / \mathrm{JSR}$

Cilt / Volume 23 Sayı / Number 2 
The first factor, timing and frequency of visits, was found to be the most determinant factor with $12.5 \%$ variance while second factor, interviewer characteristics and similarity, has $10.7 \%$ of total explained variance. Lastly, $10 \%$ of total explained variance was estimated by dynamic interview factors.

Among factor variables, start hour (0.86), timing (0.84), mean duration (0.76), enrolled student (0.74), interview length (0.62), background (0.59), field stage (0.51), age similarity (0.36), and language matching (0.31) have quite high factor loadings. On the other hand, number of visits (0.27), educational level similarity (0.19), feelings after the interview (0.17) and reliability of answers $(0.14)$ have relatively low factor loadings (Figure 2). 


\section{Figure 2. Model Illustration for Rapport between Interviewer and Respondent}

\section{(Factor loadings are presented in the parenthesis)}

Start hour (0.86)

Timing (0.84)

Number of visits $(0.27)$

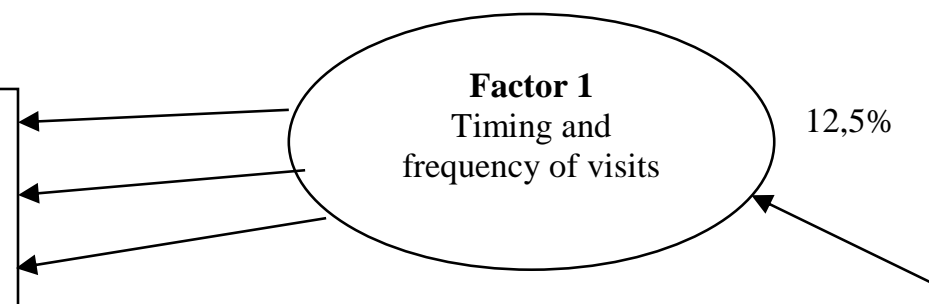

Background (0.59)

Field stage (0.51)

Age similarity (0.36)

Educational level similarity (0.19)

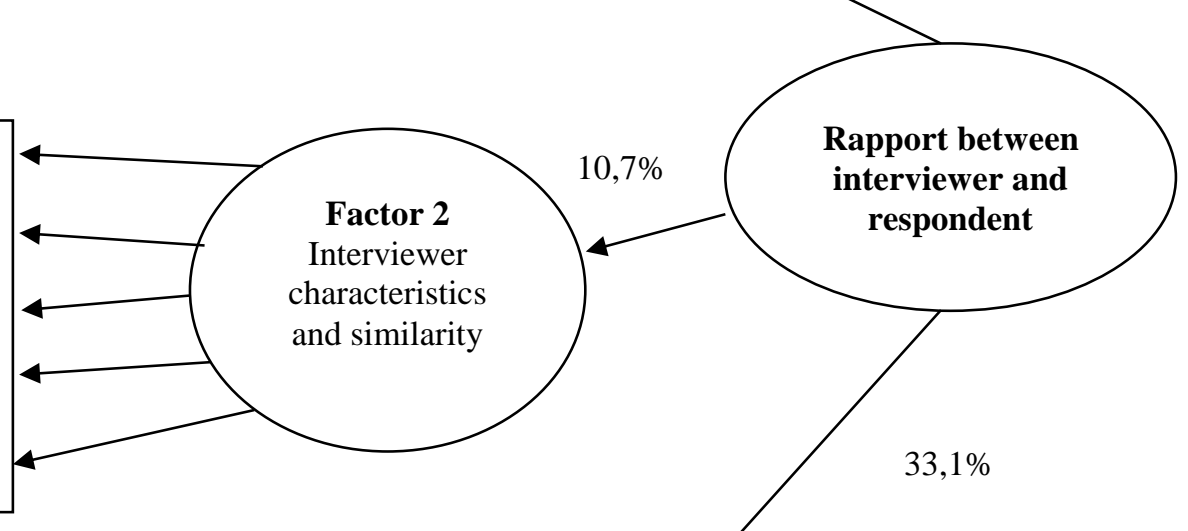

Mean duration (0.76)

Interview length (0.62)

Language matching (0.31)

Feelings after the interview (0.17)

Reliability of answers (0.14)

Factor 3

Dynamic interview factors

$9,9 \%$

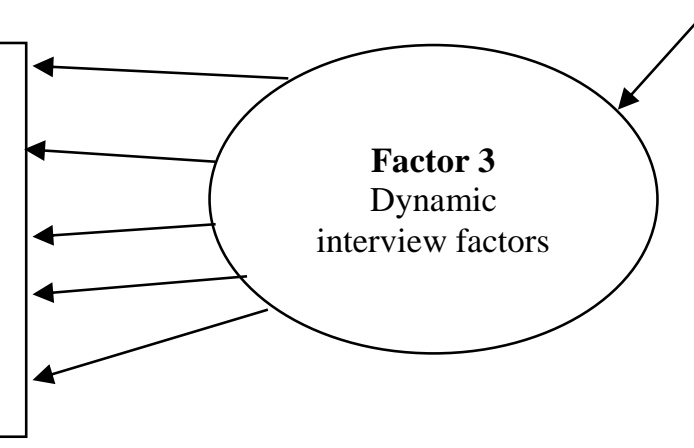




\subsection{Descriptive Statistics and Variation among Subgroups}

As a result of the distribution, 33 percent of individual interviews are classified under high rapport level while 67 percent of interviews are considered under low/middle rapport levels. In light of the descriptive findings, pairwise comparisons, which we performed the analyses on high rapport level, revealed significant variation among subgroups of women.

The percentage of interviews completed with high rapport is higher in South and Central regions (48\% and $45 \%$, respectively) compared to other regions. In line with this, the women interviews conducted in the West, North and East regions are significantly different from the South and Central $(p<0.01)$. Developing high rapport and engagement is more frequent in rural areas than urban areas (40\% and 31\%, respectively) $(p<0.01)$. The statistical comparison also indicates that interviews with high rapport is significantly more common among women who are older than 25 years, compared to women who is between 15 and 24 $(p<0.01)$. Considering the mother tongue of women, women whose mother tongue is Turkish seems more advantageous in terms of establishing high rapport $(36 \%)$ rather than women whose mother tongue is Kurdish and Arabic or other ( $21 \%$ and $25 \%$, respectively) $(p<0.01)$. When the marital status of women is considered, ever married women shows significant variation compared to never married women (35\% and $25 \%$, respectively) $(p<0.01)$ (Table 3 and Table 4$).$

The percentage of interviews completed with high rapport is higher among women who have at least one living children (35\%) and women who have at least one child under $5(36 \%)$, compared to women who have not any living children (27\%) and women who have not children under $5(32 \%)(p<0.01$ and $p<0.05$, respectively). On the other hand, number of children does not make any variation among on subgroups. The percentage of interviews conducted with high rapport is slightly higher among women who have used contraception (35\%) than women who have never used method (31\%), and these women show significant variation among each other $(p<0.05)$. Women who have stated that their general health status is bad/very 
bad in the last 4 weeks differ significantly compared to the reference category ( $35 \%$ and $31 \%$, respectively) $(p<0.01)$.

Examining the socio-economic characteristics of women, the proportion of women with no education is significantly different from educated women $(p<0.01)$. Developing high rapport is a little more often among women who are not working compared to working women ( $34 \%$ and $31 \%$, respectively) $(p<0.05)$. Similarly, women who have not any income have a slightly higher percentage compared to women who have income (34\% and $31 \%$, respectively) $(p<0.01)$. Considering wealth index, women who are in the lowest wealth quintile have higher percentage compared to women who are in the highest wealth quintile (35\% and 32\%, respectively) $(p<0.05)$ (Table 3 and Table 4$)$.

Developing high rapport seems more frequently among women who were exposed to emotional, sexual or physical violence during their life compared to reference groups (37\%, 39\% and 38\%, respectively). Moreover, women who exposed to emotional, sexual or physical violence indicate significant variation compared to reference groups ( $p<0.01, p<0.05, p<0.01$, respectively). In line with this finding, women who have at least one physical injury are significantly different from women who have not any physical injury $(p<0.01)$. Severity of physical violence does not make any variation in terms of building high rapport. The percentage of interviews completed with high rapport is higher among women whose controlling behavior index is high (37\%) compared to women with middle or low levels (34\% and 29\%, respectively) $(p<0.01)$. Establishing high rapport is a little more frequent among women who shared the suicidal thoughts compared to reference group $(p<0.05)$. Women who exposed to physical or sexual violence during their life and stated that their general health status is bad/very bad differ significantly from the other women groups $(p<0.05)$. 
Considering the attitudes towards gender roles, there is no variation among subgroups except for some items regarding refusal to have sex. Developing high rapport and engagement seem to be more frequent in interviews if women stated at least one items on refusals to have sex $(p<0.01)$. Among other variables, only cooperation rate of interviewer indicates significant variation among subgroups. Percentage of interviews conducted with an interviewer whose cooperation rate is less than 1.16 is higher than interviews conducted with an interviewer whose cooperation rate is higher than 1.15 (38\% and 32\%, respectively) ( $p<0.01)$ (Table 3 and Table 4). 
Table 3. Characteristics and attitudes of women by rapport levels

\begin{tabular}{|c|c|c|c|c|c|c|c|}
\hline & Low/middle & High & Number & & Low/middle & High & Number \\
\hline Demographic/basic & \multicolumn{7}{|c|}{ Violence related } \\
\hline Region & \multicolumn{7}{|c|}{ Emotional } \\
\hline West & 74,3 & 25,7 & 2,203 & No & 69,2 & 30,8 & 4,272 \\
\hline South & 52,1 & 47,9 & 583 & Yes & 62,7 & 37,3 & 2,643 \\
\hline Central & 55,2 & 44,8 & 1,372 & \multicolumn{4}{|l|}{ Sexual } \\
\hline North & 66,8 & 33,2 & 986 & No & 67,3 & 32,7 & 6,212 \\
\hline East & 71,2 & 28,8 & 1,777 & Yes & 60,9 & 39,1 & 701 \\
\hline Residence & \multicolumn{7}{|c|}{ Physical } \\
\hline Urban & 68,7 & 31,3 & 4,720 & No & 68,8 & 31,2 & 4,857 \\
\hline Rural & 59,5 & 40,5 & 2,201 & & 61,8 & 38,2 & 2,057 \\
\hline Age & \multicolumn{7}{|c|}{ Severity } \\
\hline $15-24$ & 71,7 & 28,3 & 1,261 & No violence & 68,8 & 31,2 & 4,865 \\
\hline $25-39$ & 65,1 & 34,9 & 2,907 & Moderate & 63,2 & 36,8 & 1,144 \\
\hline $40-59$ & 66,1 & 33,9 & 2,753 & Severe & 60 & 40,0 & 912 \\
\hline Mother tongue & \multicolumn{7}{|c|}{ Controlling behaviors } \\
\hline Turkish & 64,2 & 35,8 & 5,581 & Low & 70,9 & 29,1 & 2,258 \\
\hline Kurdish & 78,8 & 21,2 & 1,127 & Middle & 65,7 & 34,3 & 2,288 \\
\hline Arabic and other & 75,1 & 24,9 & 213 & High & 63,3 & 36,7 & 2,375 \\
\hline Marital status & \multicolumn{7}{|c|}{ Suicidal thoughts } \\
\hline Never married & 75,5 & 24,5 & 1,088 & No & 67,3 & 32,7 & 5,649 \\
\hline Ever married & 65,1 & 34,9 & 5,833 & Yes & 63,8 & 36,2 & 1,251 \\
\hline Living children & & & & Injuries & & & \\
\hline 0 & 72,6 & 27,4 & 1,505 & None & 67,3 & 32,7 & 6,385 \\
\hline 1 & 65,7 & 34,3 & 964 & At least one & 60,1 & 39,9 & 533 \\
\hline 2 & 64,9 & 35,1 & 2,081 & \multicolumn{4}{|l|}{ Violence and health } \\
\hline $3+$ & 64,9 & 35,1 & 2,371 & Else & 67,0 & 33,0 & 6,493 \\
\hline Use of contraception & & & & Violence exposure and & 61,1 & 38,9 & 428 \\
\hline Never used & 68,9 & 31,1 & 2,546 & bad health & & & \\
\hline Ever used & 65,5 & 34,5 & 4,369 & \multicolumn{4}{|l|}{ Attitudes* } \\
\hline Children under 5 & & & & \multicolumn{4}{|l|}{ Refusals to have sex } \\
\hline No & 67,8 & 32,2 & 4,843 & None & 83,4 & 16,6 & 167 \\
\hline Yes & 63,9 & 36,1 & 2,078 & At least one refusal & 66,3 & 33,7 & 6,116 \\
\hline General health & & & & & & & \\
\hline Bad/very bad & 63,6 & 36,4 & 1,981 & \multicolumn{4}{|c|}{ Refuse to have sex if: woman has health problems } \\
\hline Not bad & 67,8 & 32,2 & 4,936 & No & 75,2 & 24,8 & 294 \\
\hline Socio-economic & & & & Yes & 66,1 & 33,9 & 6,472 \\
\hline Educational level & \multicolumn{7}{|c|}{ Other variables* } \\
\hline No education & 72,5 & 27,5 & 1,271 & \multicolumn{4}{|l|}{ Cooperation rate } \\
\hline Primary and higher & 65,6 & 34,5 & 5,650 & More than 1.15 & 68,3 & 31,7 & 4,234 \\
\hline Working status & & & & Less than 1.16 & 61,6 & 38,4 & 2,687 \\
\hline No & 65,7 & 34,3 & 4,857 & Total & 66,7 & 33,3 & 6,967 \\
\hline Yes & 68,8 & 31,2 & 2,061 & \multirow{5}{*}{\multicolumn{4}{|c|}{$\begin{array}{l}\text { *The items for other attitudes and variables do not differ } \\
\text { significantly based on rapport levels. }\end{array}$}} \\
\hline Wealth index & & & & & & & \\
\hline Low & 65,0 & 35,0 & 2,990 & & & & \\
\hline Middle & 66,0 & 34,0 & 1,405 & & & & \\
\hline High & 68,4 & 31,6 & 2,526 & & & & \\
\hline \multicolumn{8}{|l|}{ Income status } \\
\hline No & 65,5 & 34,5 & 5,293 & & & & \\
\hline Yes & 69,9 & 30,1 & 1,627 & & & & \\
\hline \multicolumn{8}{|l|}{ Spending earnings } \\
\hline No & 66,1 & 33,9 & 5,579 & & & & \\
\hline Yes & 68,9 & 31,1 & 1,342 & & & & \\
\hline Total & 66,7 & 33,3 & 6,967 & & & & \\
\hline
\end{tabular}

$\mathrm{SAD} / \mathrm{JSR}$

Cilt / Volume 23 Sayı / Number 2 


\section{Table 4. Significance Values in Pairwise Comparisons}

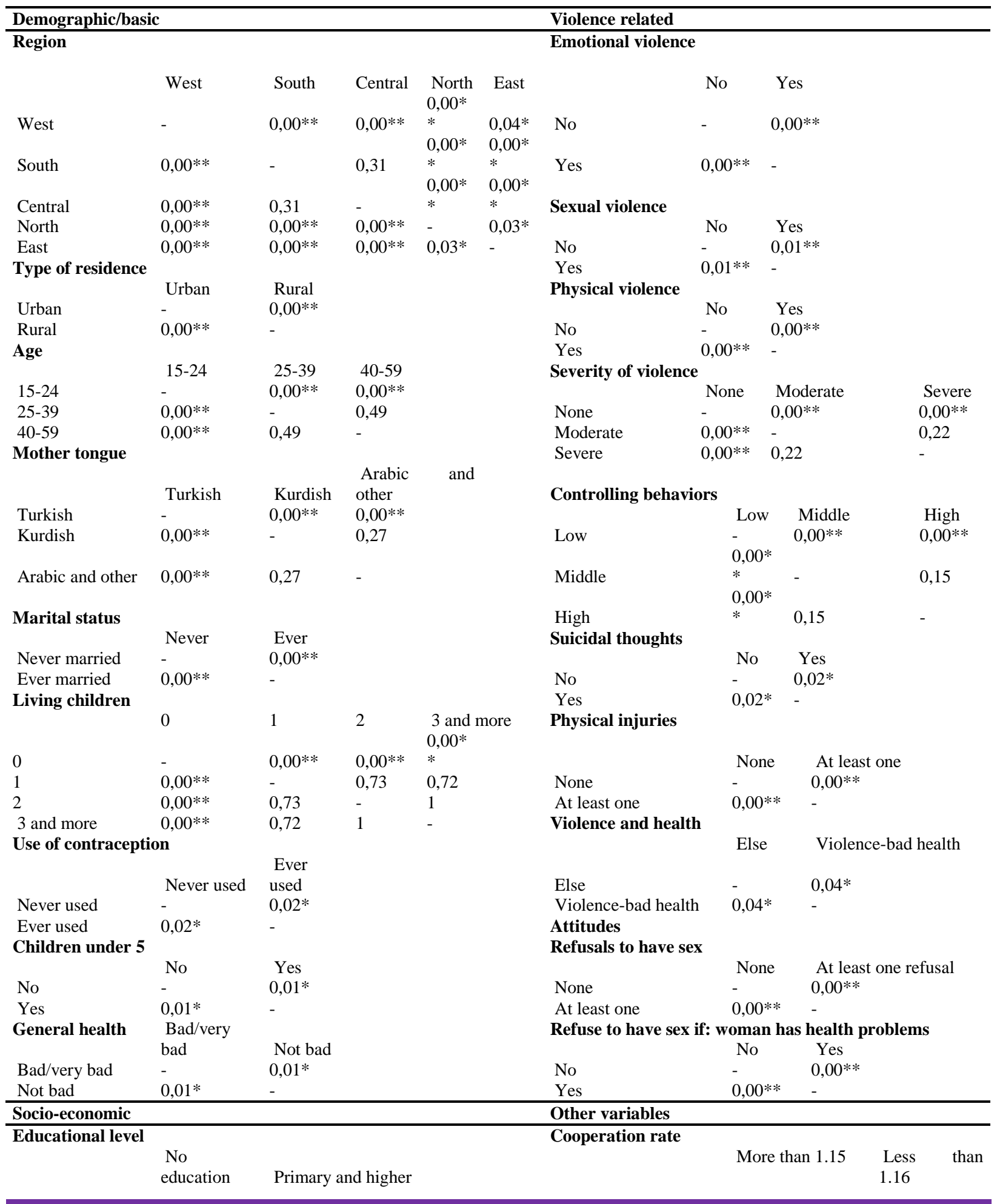

$\mathrm{SAD} / \mathrm{JSR}$

Cilt / Volume 23 Say1 / Number 2 
Exploring Factors to Build Rapport Between

National Research on Domestic Violence against

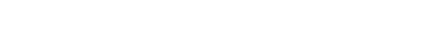

Women in Turkey

\begin{tabular}{|c|c|c|c|c|c|c|}
\hline \multicolumn{4}{|l|}{ Educational level } & \multicolumn{3}{|c|}{ Cooperation rate } \\
\hline No education & - & \multicolumn{2}{|l|}{$0,00 * *$} & More than 1.15 & \multirow[t]{2}{*}{-} & \multirow[t]{2}{*}{$0,00 * *$} \\
\hline Primary and & & & & Less than 1.16 & & \\
\hline higher & $0,00 * *$ & - & & & $0,00 * *$ & - \\
\hline \multicolumn{4}{|l|}{ Working status } & & & \\
\hline & No & Yes & & \multirow{3}{*}{\multicolumn{3}{|c|}{$\begin{array}{l}* * \text { refers significance at the } 0.01 \text { level, and * refers } \\
\text { significance at the } 0.05 \text { level of t-tests comparing to } \\
\text { reference category on the raw. }\end{array}$}} \\
\hline No & - & $0,04 *$ & & & & \\
\hline Yes & $0,04 *$ & - & & & & \\
\hline \multicolumn{7}{|l|}{ Wealth index } \\
\hline & Low & Middle & High & & & \\
\hline Low & - & 0,57 & $0,04^{*}$ & & & \\
\hline Middle & 0,57 & - & 0,22 & & & \\
\hline High & $0,04 *$ & 0,22 & - & & & \\
\hline \multicolumn{7}{|l|}{ Income status } \\
\hline & No & Yes & & & & \\
\hline No & - & $0,01 * *$ & & & & \\
\hline Yes & $0,01 * *$ & - & & & & \\
\hline \multicolumn{7}{|l|}{ Spending earnings } \\
\hline & No & Yes & & & & \\
\hline No & - & 0,12 & & & & \\
\hline Yes & 0,12 & - & & & & \\
\hline
\end{tabular}

$\mathrm{SAD} / \mathrm{JSR}$

Cilt / Volume 23 Say1 / Number 2 


\section{CONCLUSIONS AND DISCUSSION}

In this paper, we explored the factors to build rapport between interviewer and respondent by using the recent Research on Domestic Violence against Women in Turkey (GDSW and HUIPS, 2015) and investigated whether there is any variation on the high level of rapport among subgroups. Considering the findings of the first stage of the study, this paper provides a conceptual contribution that it helped to extend rapport definition by using three different factors. Furthermore, the study findings showed that liking theory and social distance concept are explanatory due to the fact that the similarities in the age and educational level between respondents and interviewers have a positive impact on rapport building in the interview process. In other words, the findings of the study support the arguments of the liking theory and the concept of distance, that both describe the (un)familiarity between people in terms of socio-demographics and attitudes, as well as its impact on establishing relationship (Groves, Cialdini and Couper, 1992). This confirms our expectation at the beginning that the rapport between interviewers and respondents is influenced from whether they have similar socio-demographic characteristics or not. The results of second stage of the study suggested the significant variation among subgroups of women for most of the selected variables.

Results of the first research question pointed out that frequency and timing of visits, interviewer characteristics and similarity and dynamic interview factors are able to explain rapport established between interviewer and respondent. Similar results regarding with the rapport exploration were also found in the previous studies (Foucault et al., 2013; Goudy and Potter, 1975; Sheatsley, 1951; Weiss, 1968; Williams $\mathrm{Jr}, 1968)$. The interviewer characteristics and similarity and dynamic interview factors also confirm that rapport is a dynamic and interactive phenomenon and influenced from each individual as suggested by Sun (2014) and Tickle-Degnen and Rosenthal (1990). Durrant et al. (2010) also underlined the similarity between respondent and interviewer to improve survey response. 
Our study also shows that interviewers' opinions and feelings related to interview, namely 'reliability of answers' and 'feelings after the interview' contribute to identification of rapport as suggested in the studies (Goudy and Potter, 1975; Weiss, 1968). In our study, educational level similarity is found a contributing factor of rapport between interviewer and respondent. In line with this finding, the significant impact of similarity in educational level similarity between interviewers and respondents was discussed within the context of giving more substantive answers to knowledge and attitude questions (Yang and Yu, 2008). In our study, timing of visits and field stage contributed to establish rapport between interviewer and respondent. These variables were also discussed within the context of quality of data by considering working hours of respondents (Johnson et al., 2009).

Considering the first stage findings, the study provides statistical evidence on the rapport identification which was mentioned based on the field observations or interviewer behaviors previously. In this sense, the principal contribution of this study to existing literature is that an unobservable concept, namely rapport between interviewer and respondent, can be identified in the light of three different factors. This study goes further and also provides statistical evidence on revealing variation among women whose interviews conducted with high rapport and engagement. In the study, less than $1 \%$ and $5 \%$ significance levels of the variability among interviews with high rapport were found for most of the selected women characteristics.

The significant residential difference may be attributable to warm relations established with individuals who live in rural areas in Turkey. Similarly, South and Central regions are known as rural migrant receiving regions and people who live in these regions may have rural characteristics. The relatively high response rates in rural areas also remind more cooperation with the respondent. The rate of respondent contact and agreement to survey participation might be influenced from interviewers (Durrant and Steele, 2009). In the VAW study, women response rate in rural areas was estimated as 87 percent whereas response rate in urban 
areas was estimated as 82 percent. The response rate among regions ranges between 72 percent in West Anatolia and 88 percent in Southeast Anatolia, Northeast Anatolia, and Aegean (GDSW and HUIPS, 2015).

The significantly higher proportion of interviews conducted with high rapport was found among women who are older than 25 compared to women who are between 15 and 24 . This finding may be linked to privacy concerns and relatively low tendency of giving information among young women. Significantly higher percentage are found among women who are currently or formerly married, women who have at least one living child, and women who have at least one child under 5 compared to reference groups. The length of interview will increase depending on a set of questions on marital status, reproductive health and children, husband's background characteristics, and relationship between women and their husband and might help to build better engagement with respondent.

The high rapport built with women who are in the lowest wealth quintile, women who are not working and women who have not income may be associated with relatively high cooperation in terms of both finding at home and providing acquiescence. On the contrary, the higher percentage was found among educated women compared to women with no education. To make further explanations, multivariate analyses are needed though it might be related to comfortable interaction when answering questions and giving answers.

Taken together, our findings suggested variation between women who exposed to emotional/sexual/physical violence and women have not exposed to violence during their life. As a consistent finding, the significant variation also found among women who exposed to violence and stated that their general health is bad/very bad. According to VAW study results, 36 percent of women exposed to physical violence, 12 percent of women exposed to sexual violence, and 44 percent of women exposed to emotional violence in any time during their life (GDSW and HUIPS, 2015). Having at least one physical injury and high controlling behaviors by husbands provide consistent estimates with the violence exposure. 
Overall, not only exposure to violence but at the same time, willingness to share this information with an interviewer may be a highly sensitive issue. This situation could lead to high privacy matters and emotional burden of respondents and interviewers. Hence, giving honest answers to the sensitive questions requires confidentiality provided with high rapport between respondent and the interviewer.

Among other variables, cooperation rate of interviewer might be associated with interviewer burden during fieldwork. As Japec (2008) suggested, less interviewer burden may result in interviewer satisficing and feeling comfortable. Consequently, this may contribute to high degree of rapport.

The authors believe that this is the first study which provides a new insight on rapport identification considering interviewer and respondent characteristics as well as interview related factors in Turkey. The study also contributes to survey stages through the findings and suggestions. Being aware of differentials among women at the questionnaire design, training and data collection stages will help to obtaining better data. Our findings also suggest that different approaches to measure rapport will contribute to literature regarding interviewer and respondent relations. Furthermore, investigating the role of rapport between interviewer and respondent on the disclosure of answers will give better insights.

Undoubtedly, the discussions and our inferences on significant variation among women groups require further studies that focus on mechanisms behind developing high rapport. Moreover, it is obvious that studies which are designed to investigate interaction between respondent and interviewer are required in order to discuss the rapport with its pros and cons. Unfortunately, the data sets do not provide information about behaviors of interviewers, interviewing techniques, respondent's assessments, and other variables which refer to similarity between respondent and interviewer to measure rapport extensively (Dijkstra, 1987; Foucault et al., 2013; Foucault Welles, 2010; Goudy and Potter, 1975; Gubrium et al., 2012; 
National Research on Domestic Violence against

Women in Turkey

Sheatsley, 1951; Weiss, 1968). In that sense, the study also calls for further studies which aim to investigate all influencing factors on better engagement. 


\section{ÖZET}

Sosyal araştırmalarda görüşme sürecinin görüşmeci ve cevaplayıcı açısından değerlendirilmesi örnekleme dışı hataları minimize etmek açısından büyük bir öneme sahiptir. Özellikle yüz yüze yapılan görüşmelerde, yalnızca görüşmecilerin veya cevaplayıcıların özellikleri değil, aynı zamanda birbirleriyle kurdukları etkileşimin de veri kalitesine etkisi bulunmaktadır. $\mathrm{Bu}$ nedenle görüşmeci ve cevaplayıcı arasındaki uyumun doğru, tam ve güvenilir veri elde edilmesinde katkısı bulunmaktadır.

Türkiye'de sosyal araştırmaların metodolojisine dayanan çalışmalar oldukça az sayıdadır. Bu çalışma, ülke düzeyinde temsiliyeti bulunan bir örneklem araştırması olan Türkiye'de Kadına Yönelik Aile İçi Şiddet Araştırması (2014) ve bu araştırmanın Saha Personeli verilerini kullanarak görüşmeci ve cevaplayıcı arasındaki ilişkiyi tanımlamayı hedeflemektedir. Bu amaca ulaşmak için, nicel analiz yöntemlerinden birisi olan Keşfedici Faktör Analizi (Exploratory Factor Analysis) kullanılarak görüşmeci ve cevaplayıc1 arasındaki uyum, görüşmeci özellikleri, görüşmeci-cevaplayıcı özellikleri ve görüşme özellikleri ile açıklanmaya çalışılmıştır. Çalışmanın bir diğer amacı da yüksek uyum ile görüşmelerini tamamlayan cevaplayıcılar arasındaki farklılıkları ortaya koymaktır. Bu amaca ulaşmak için ise Kompleks Örneklem Genelleştirilmiş Lineer Model (Complex Sample Generalized Linear Model-CSGLM) istatistiksel tekniği kullanılmıştır. Böylelikle cevaplayıcılar seçilen birtakım sosyo-demografik ve sosyo-ekonomik özelliklerin yanı sıra hassasiyet düzeyi daha yüksek olan şiddet ile ilgili değişkenler bağlamında değerlendirilebilmiştir. Tüm analiz yöntemleri Türkiye'de Kadına Yönelik Aile İçi Şiddet Araştırması'nın kompleks örneklem tasarımı dikkate alınarak uygulanmıştır. Görüşmeci ve cevaplayıcı arasında tanımlanan uyum kavramının düzeylerini belirlemek ise bu çalışmanın bir alt amacıdır. Uyum düzeylerini belirlemede yansız bir yaklaşım benimsenmiştir.

Çalışmanın sonuçları, ziyaretlerin zamanlaması ve sıklı̆̆ı, görüşmeci özellikleri ve benzerlik ile dinamik görüşme faktörlerinin görüşmeci ve cevaplayıcı arasındaki uyumu oluşturan faktörler olduğunu 
göstermektedir. Benzer sonuçlara diğer ülkelerde yapılan araştırmalara ilişkin çalışmalarda da rastlanmaktadır. Görüşmeci özellikleri ve görüşmeci-cevaplayıcı benzerliği ile dinamik görüşme faktörleri görüşme sürecinin dinamik ve etkileşimli bir yapıya sahip olduğunu doğrulamaktadır.

Ayrıca analiz sonuçları, görüşmeleri yüksek uyum ile tamamlanmış kadın grupları arasında anlamlı sosyodemografik ve sosyo-ekonomik özelliklerin olduğuna işaret etmektedir. Bunun yanı sıra, görüşmeleri yüksek uyum ile tamamlanmış kadın grupları şiddete maruz kalma ve eş tarafından uygulanan kontrol edici davranışlar gibi daha hassas değişkenlere göre de anlamlı olarak değişmektedir.

Özetle, bu çalışma sosyal araştırmalarda görüşmeci ve cevaplayıcı arasındaki uyumu Türkiye'de Kadına Yönelik Aile İçi Şiddet Araştırması örneği ile tanımlamıştır. Ayrıca görüşmeleri yüksek uyum ile tamamlanmış kadın grupları arasında farklılıklar olduğu hipotezini test etmiştir. Bu anlamda, görüşmeci ile cevaplayıcı arasındaki uyumun kavramsal faktörlerle açıklanması literatüre teorik olarak katkı sağlamaktadır. Cevaplayıcılar arasındaki farklılıkların ortaya konulması ise saha araştırmalarında soru kağıdı tasarımı, eğitim ve veri toplama gibi aşamalarda uygulamaya dönük stratejilerin benimsenebileceğini göstermektedir.

$\mathrm{Bu}$ çalışma ayrıca, görüşmeci ve cevaplayıcı arasındaki uyumun görüşmeci ve cevaplayıcı davranışları, görüşme tekniği ile görüşmeci ve cevaplayıcı arasındaki benzerliği yansıtan diğer değişkenler gibi faktörlerle kapsamlı olarak ele alan ve görüşmeci ile cevaplayıcı arasındaki uyumun veri kalitesine etkisini inceleyecek çalışmalara duyulan ihtiyacı göstermektedir.

$\mathrm{SAD} / \mathrm{JSR}$

Cilt / Volume 23 Sayı / Number 2 


\section{REFERENCES}

Amos, M. (2018). Interviewer Effects on Patterns of Nonresponse: Evaluating the Impact on the Reasons for Contraceptive Nonuse in the Indonesia and the Philippines DHS. Demographic Research, 39, 415-430.

Bell, K., Fahmy, E., \& Gordon, D. (2016). Quantitative Conversations: The Importance of Developing Rapport in Standardized Interviewing. Quality \& Quantity, 50(1), 193-212.

Belli, R. F., Lepkowski, J. M., \& Kabeto, M. U. (2001). The Respective Roles of Cognitive Processing Difficulty and Conversational Rapport on the Accuracy of Retrospective Reports of Doctor's Office Visits. ML Cynamon and RA Kulka (Eds.), In Seventh Conference on Health Survey Research Methods, (pp. 197-203), Hyattsville, Maryland: Department of Health and Human Services, Centers for Disease Control and Prevention, National Center for Health Statistics.

Berk, M. L., Bernstein, A. B. (1988). Interviewer Characteristics and Performance on a Complex Health Survey. Social Science Research, 17(3), 239-251.

Biemer, P. P., Lyberg, L. E. (2003). Introduction to Survey Quality (Vol. 335). Hoboken, New Jersey: John Wiley \& Sons.

Byrne, D. (1971). The Attraction Paradigm. New York: Academic Press.

Campanelli, P., Sturgis, P., \& Purdon, S. (1997). Can You Hear me Knocking? And Investigation into the Impact of Interviewers on Survey Response Rates. London, GB: National Centre for Social Research.

Cappella, J. N. (1990). On Defining Conversational Coordination and Rapport. Psychological Injury, 1(4), 303-305.

Channon, A. A. R., Padmadas, S. S., \& McDonald, J. W. (2011). Measuring Birth Weight in Developing Countries: Does the Method of Reporting in Retrospective Surveys Matter? Maternal and Child Health Journal, 15(1), 12-18.

Corsi, D. J., Perkins, J. M., \& Subramanian S. V. (2017). Child Anthropometry Data Quality from Demographic and Health Surveys, Multiple Indicator Cluster Surveys and National Nutrition 
Surveys in the West Central Africa Region: Are We Comparing Apples and Oranges? Global Health Action, 10(1), 1328185.

Davis, R. E., Couper, M. P., Janz, N. K., Caldwell, C. H., \& Resnicow, K. (2009). Interviewer Effects in the Public Health Surveys. Health Education Research, 25(1), 14-26.

Dijkstra, W. (1987). Interviewing Style and Respondent Behavior: An Experimental Study of SurveyInterview. Sociological Methods \& Research, 16(2), 309-334.

Drachman, D., de Carufel, A., \& Insko, C.A. (1978). The Extra Credit Effect in Interpersonal Attraction. Journal of Experimental Social Psychology, 14, 458-467.

Durrant, G. B., D’Arrigo, J. (2014). Doorstep Interactions and Interviewer Effects on the Process Leading to Cooperation or Refusal. Sociological Methods \& Research, 43(3), 490-518.

Durrant, G. B., Steele, F. (2009). Multilevel Modelling of Refusal and Non-Contact in Household Surveys: Evidence from Six UK Government Surveys. Journal of the Royal Statistical Society: Series A (Statistics in Society), 172(2), 361-381.

Durrant, G. B., Groves, R. M., Staetsky, L., \& Steele, F. (2010). Effects of Interviewer Attitudes and Behaviors on Refusal in Household Surveys. Public Opinion Quarterly, 74(1), 1-36.

Fabrigar, L. R., Wegener, D. T. (2011). Exploratory Factor Analysis. New York: Oxford University Press.

Fernandez-Ballesteros, R., Zamarron, M. D., \& Ruiz, M. A. (2001). The Contribution of SocioDemographic Psychosocial Factors to Life Satisfaction. Ageing \& Society, 21(1), 25-43.

Flores-Macias, F., Lawson, C. (2008). Effects of Interviewer Gender on, Survey Responses: Findings from a Household Survey in Mexico. International Journal of Public Opinion Research, 20(1), 100-110.

Foucault Welles, B. (2010). Non-Verbal Correlates of Rapport in Face-to-Face Survey Interviews: An Analysis of Interviewer Behavior (p. 291). Presentation at the American Association Public Opinion Research Conference. Chicago, Illinois. Retrieved from: https://www.aapor.org/AAPOR_Main/media/MainSiteFiles/AAPOR2010ConferenceAbstracts.pdf

Foucault, B., Aguilar, J., Miller, P. \& Cassell, J. (2013). Behavioral Correlates of Rapport in Survey Interviews. Presentation at the Interviewer-Respondent Interaction Workshop. Boston, MA.

$\mathrm{SAD} / \mathrm{JSR}$

Cilt / Volume 23 Say1 / Number 2 
Fowler Jr., F. J., Mangione, T. W. (1990). Standardized Survey Interviewing: Minimizing InterviewerRelated Error. (Vol. 18). California: Sage.

Garbarski, D., Schaeffer, N. C., \& Dykema, J. (2016). Interviewing Practices, Conversational Practices, and Rapport: Responsiveness and Engagement in the Standardized Survey Interview. Sociological Methodology, 46(1), 1-38.

GDSW, HUIPS. (2015). Research on Domestic Violence against Women in Turkey. Ankara.

Goudy, W. J., Potter, H. R. (1975). Interview Rapport: Demise of Concept. Public Opinion Quarterly, 39(4), 529-543.

Green, M. C., Krosnick, J. A. (2001). Comparing Telephone and Face-to-Face Interviewing in Terms of Data Quality: The 1982 National Election Studies Method Comparison Project. Health Survey Research Methods, 115-121.

Groves, R. M., Cialdini, R. B., \& Couper, M. P. (1992). Understanding the Decision to Participate in a Survey, Public Opinion Quarterly, 56(4), 475-495.

Gubrium, J. F., Holstein, J. A., Marvasti, A. B., \& McKinney, K. D. (2012). The SAGE Handbook of Interview Research: The Complexity of the Craft. USA: Sage.

Hair, J. F., Black W. C., Babin, B. J., Anderson, R. E., \& Tatman, R. L. (1998). Multivariate Data Analysis (Bol. 5). Prentice hall Upper River, NJ.

Hansen, K. M. (2006). The Effects of Incentivesi Interview Length, and Interviewer Characetristics on Response Rates in a CATI-Study. International Journal of Public Opinion Research, 19(1), 112121.

Hodgetts D., Stolte, O. (2014). Social Distance. In Teo (Eds.), Encyclopedia of Critical Psychology, Springer.

Hox, J. J., De Leeuw, E. D., \& Kreft, G. G. (1991). The Effect of Interviewer and Respondent Characteristics on the Quality of Survey Data: A Multilevel Model. In Biemer, Groves, Lyberg, Mathiowetz, and Sudman (Eds.), Measurement Errors in Surveys, (pp.439-461). Wiley \& Sons.

$\mathrm{SAD} / \mathrm{JSR}$

Cilt / Volume 23 Say1 / Number 2 
Hox, J. J., De Leeuw, E. D., Couper, M. P., Groves, R. M., De Heer, W., \& Kuusela, V. (2002). The Influence of Interviewers' Attitude and Behavior on Household Survey Nonresponse: An International Comparison. Survey Nonresponse, 103-120.

Japec, L. (2008). Interviewer Error and Interviewer Burden. In Lepkowski, Tucker, Brick, De Leeuw, Japec, Lawrakas, Link, Sangster (Eds.), Advances in Telephone Survey Methodology, (185-211). Wiley Series in Survey Methodology.

Johnson, K., Grant, M., Khan, S., Moore, Z., \& Armstrong, A. (2009). Fieldwork-Related Factors and Data Quality in the Demographic and Health Surveys Program. DHS Analytical Studies No. 19. Calverton, Maryland, USA: ICF Macro.

Johnson, T. P., Fendrich, M., Shaligram, C., Garcy, A., \& Gillespie, S. (2000). An Evaluation of the Effects of Interviewer Characteristics in An RDD Telephone Survey of Drug Use. Journal of Drug Issues, 30(1), 77-101.

Katz, D. (1942). Do Interviewers Bias Poll Results? Public Opinion Quaretrly, 6(2), 248-268.

Lavin, D., \& Maynard, D. W. (2001). Standardization vs. Rapport: Respondent Laughter and Interviewer Reaction during Telephone Surveys. American Sociological Review, 453-479.

Lipman-Blumen, J. (1976). Toward a Homosocial Tehory of Sex Roles: An Explanation of the Sex Segregarion of Social Institutions. Signs: Journal of Women in Culture and Society, 1 (3, Part 2), $15-31$.

Lipps, O., \& Lutz, G. (2010). How Answers on Political Attitudes are Shaped by Interviewers: Evidence from A Panel Survey. Swiss Journal of Sociology, 2, 345-358.

Mensch, B. S., \& Kandel, D. B. (1988). Underreporting of Substance Use in A National Longitudinal Youth Cohort: Individual and Interviewer Effects. Public Opinion Quarterly, 52(1), 100-124.

Olson, K., Bilgen, I. (2011). The Role of Interviewer Experience on Acquiescence. Public Opinion Quarterly, 75(1), 99-114.

Olson, K., Peytchev, A. (2007). Effect of Interviewer Experience on Interview Pace and Interviewer Attitudes. Public Opinion Quarterly, 71(2), 273-286. 
Oyinlade, A. O., Losen, A. (2014). Extraneous Effects of Race, Gender, and Race-Gender Homo and Heterophily Conditions on Data Quality. SAGE Open, 4(1), DOI: 2158244014525418.

Pickery, J., Loosveldt, G., \& Carton, A. (2001). The Effects of Interviewer and Respondent Characteristics on Response Behavior in Panel Surveys: A Multilevel Approach. Sociological Methods \& Research, 29(1), 509-523.

Schnell, R., Kreuter, F. (2005). Separating Interviewer and Sampling-Point Effects. Journal of Official Statistics, 21(3), 389-410.

Schober, M. F. (2016). Rapport in Survey Interactions. Sociological Methodology, 46(1), 43-46.

Sheatsley, P. B. (1951). The Art of Interviewing and A Guide to Interviewer Selection and Training. Research Methods in Social Relations, 2.

Singer, E., Frankel M. R., \& Glassman, M. B. (1983). The Effect of Interviewer Characteristics and Expectations on Response. Public Opinion Quarterly, 47(1), 68-83.

Stotland, E., Patchen, M. (1961). Identification and Change in Prejudice and Authoritarianism. Journal of Abnormal and Social Psychology, 62, 250-256.

Sun, H. (2014). Rapport and Its Impact on the Disclosure of Sensitive Information in Standardized Interviews (Doctoral Dissertation). Retrieved from: https://isr.umich.edu/wpcontent/uploads/2017/09/Dissertation_HSun_final2.pdf

Tickle-Degnen, L., Rosenthal, R. (1990). The Nature of Rapport and Its Nonverbal Correlates. Psychological Inquiry, 1(4), 285-293.

Van der Zouwen, J., Dijkstra, W., \& Smit, J. H. (2004). Studying Respondent-Interviewer Interaction: The Relationship between Interviewing Style, Interviewer Behavior, and Response Behavior. In Biemer, Groves, Lyberg, Mathiowetz, and Sudman (Eds.), Measurement Errors in Surveys, (419437). Wiley \& Sons.

Vercruyssen, A., Wuyts, C., \& Loosveldt, G. (2017). The Effect of Sociodemographic (Mis)Match betweeen Interviewer and Respondents on Unit and Item Nonresponse in Belgium. Social Science Research, 67, 229-238. 
Wang, J., Tolson, H., Chiang, T. L., \& Huanf, T. Y. (2010). An Exploratory Factor Analysis of Workplace Learning, Job Satisfaction, and Organizational Commitment in Small to Midsize Enterprises in Taiwan. Human Resource Development International, 13(2), 147-163.

Weeks, M. F., Moore, R. P. (1981). Ethnicity of Interviewer Effects on Ethic Respondents. Public Opinion Quarterly, 45(2), 245-249.

Weiss, C. H. (1968). Validity of Welfare Mothers' Interview Responses. Public Opinion Quarterly, 32(4), 622-633.

WHO Department of Gender and Women's Health (2001). Putting Women First: Ethical and Safety Recommendations for Research on Domestic Violence against Women. Geneva: WHO publications. Retrieved from https://www.who.int/gender/violence/womenfirtseng.pdf

Williams Jr, J. A. (1968). Interviewer Role Performance: A Further Note on Bias in the Information Interview. Public Opinion Quarterly, 32(1), 287-294.

Williams Jr, J. A. (1964). Interviewer-Respondent Interaction: A Study of Bias in the Information Interview. Sociometry, 27(3), 338-352.

Yang, M. L., Yu, R. R. (2008). The Interviewer Effect When There is An Education Gap with the Respondent: Evidence from A Survey on Biotechnology in Taiwan. Social Science Research, 37(4), 1321-1331. 